008(497.11)(510)

https://doi.org/10.18485/fb_bri_se.2019.ch9

Radosav Pušić

Faculty of Philology, University of Belgrade

\title{
The New Silk Road: Cultural Cooperation between Serbia and China
}

\begin{abstract}
Even a superficial look at the Chinese Belt and Road Initiative, Silk Road Economic Belt and 21st-century Maritime Silk Road development strategy reveals with how much attention, desire and passion this way of connecting the world was designed. Serbia and China, two countries incomparable in many respects, can be compared in terms of their boundless wish to preserve their authenticity and freedom. Culture and art are not only the carriers of the soul and spiritual values of a nation, but in many respects the foundation of all relations between countries. Every relationship is culture or lack of culture, depending on our viewpoint. Even though it might not appear so at first sight, culture, regardless of how we define it, has to lie at the heart of every plan for sustainable development of economy, science and all other spheres of societies which deeply respect and promote essential aspects of human creativity and freedom. Were it not so, everything pertaining to man would become meaningless.

This brief overview of cultural relations between Serbia and China, within the Belt and Road Initiative, describes the points of great importance for the relationship between our two countries in the last decade or so.
\end{abstract}

Keywords:

culture, freedom, sense, Serbia, China

Although a small country, Serbia has great political significance in the Balkans and Europe owing to its geographic location at the crossroads of Southeastern Europe, where important waterways and land routes meet.

Despite obvious differences in size and significance, China and Serbia first became strategic (2009) and then comprehensive strategic partners $(2013,2016)$. Applying the principles promoted in the Belt and Road project, 
they have begun implementing joint projects in areas such as energy, transportation, agriculture, telecommunications, finance and academic and cultural exchange. These include the Zemun-Borča bridge, the Kostolac thermal power plant, the Belgrade-Budapest high-speed rail, the steel manufacturer Železara Smederevo, the Bor copper mining and smelting complex, the tire factory in Zrenjanin, the Surčin-Obrenovac freeway, the renewal of Serbia's energy supply system and telecommunications network, the introduction of the UnionPay financial services network, etc. China, on the other hand, is extremely important to Serbia as one of the key actors in global politics and a country that has maintained friendly relations with Serbia. Given the adversities and tragic events in Serbia's recent history, good relations between China and Serbia have an impact not only on Serbia's development but are also vital for its stability and prosperity.

\section{1.}

If it is indeed true that the project, idea, dream, or vision of the Belt and Road, launched by Chinese President Xi Jinping in 2013, is enhancing regional economic integration, connecting numerous strategic and geostrategic locations, and making the world more global and closely connected than it has ever been, then these infrastructural connections between countries, regions and parts of the world can be seen as an opportunity, chance, possibility, or need. Italy and Greece have joined the project, alongside sixteen countries in Central and Eastern Europe and the five BRICS countries, adding to the number of countries that wish to participate in the implementation of the Belt and Road. As in life, such long-term projects require certain preconditions, a certain mindset and a specific environment.

The BRICS banks and the founding of Chinese investment banks (the Asian Infrastructure Investment Bank (AIIB)) are undoubtedly an alternative to the International Monetary Fund (IMF) and the World Bank. Various actions taken by Eurasian countries, including China, Russia and Iran, are aimed at creating stable, sustainable and self-sufficient regions of cooperation out of regions plagued by endless conflict, war and instability. The multipolar world is characterized by great diversity, mutual respect and cooperation. If they are exercised in good faith, divergent worldviews, unequal starting points, differing philosophies of life, civilizational differences and disparate cultural patterns do not necessarily need to lead to tragic developments, struggle, adversity and conflict. Furthermore, the 
question arises as to whether the logic of military-industrial complexes and banks will preserve their hegemony and continue to lead the world into new "circles of hell" or whether opportunities will present themselves to embrace different spatio-temporal and ideational coordinates. Regardless of how we choose to describe the world, it is difficult to say from today's perspective how numerous unresolved issues will be settled and how history will unfold.

But let us go back to the mosaic we mentioned earlier.

After the 2008 financial crisis, China's economy remained stable and it demonstrated the capability of weathering the most complex financial difficulties. China and Russia are using national currencies, rather than dollars, in trade and energy agreements. This is an important first step in creating the conditions for a different world. An interbank system independent of Western financial institutions is a precondition for providing new starting points in the creation of a multipolar world.

To this end, a competition has begun between two concepts, two value matrices, two conflicting ideas - the ideas of the "old" and "new" worlds, of the imperial colonial world and the free world. Those prone to religious simplifications describe it as a fight between "good and evil", between "light and darkness", "freedom and slavery"... This poses issues as soon as we attempt to understand the very essence of good, evil, light, darkness, freedom... The dangers posed by simplifications of violent and destructive forces, blundering, and intolerance are not insignificant.

Even those with a superficial knowledge about Chinese civilization are aware that for the Chinese people time is not a real category. The body, the soul and the spirit converge around values from which meaning is derived. These were given different names at different times in the history of Chinese civilization depending on its dynastic cycles: love, benevolence, knowledge, wisdom, faith, being in harmony with cosmic energy flows, etc. Upholding these axiomatic elements of tradition, China has begun its entry into modernity and, given such heritage, it is undertaking the implementation of the Belt and Road in a similar way.

It has been clear from the beginning that there are no blocs or special alliances; everything depends on the situation at hand and each situation is unique. China does not try to influence the relations between countries - they are as they are and should be determined by life itself and by practical experience. This is why, for example, China sometimes applies the principles of "business before politics", "development before democracy" and "mutual non-interference in internal affairs", which are conducive to a flexible entrepreneurial spirit based on mutual respect. This starting position reflects the fact that that these projects will not be instances of 
imperialist expansion and that China will wait for other countries to put forward their propositions, which will then be implemented after mutual agreement and interests have been arrived at and certain conditions have been met. Or, as Chinese President said in Davos in 2017: "We should strike a balance between efficiency and equity to ensure that different countries, different social strata and different groups of people all share in the benefits of economic globalization. The people of all countries expect nothing less from us, and this is our unshirkable responsibility as leaders of our times. [...] Today, mankind has become a close-knit community of shared future. Countries have extensive converging interests and are mutually dependent. All countries enjoy the right to development. At the same time, they should view their own interests in a broader context and refrain from pursuing them at the expense of others. [...] Countries, big or small, strong or weak, rich or poor, are all equal members of the international community. As such, they are entitled to participate in decision-making, enjoy rights and fulfil obligations on an equal basis."

Let us provide a broad overview of how the favourable conditions for the Belt and Road are gradually being created.

In November 2008, Chinese President Hu Jintao signed a $\$ 3.4$ billion arrangement allowing the China Ocean Shipping Company (COSCO) to upgrade and run part of Greece's main port in Piraeus. This opened up the opportunity to build a third dock and increase the port's capacity with the aim of tripling its transport and transhipment operations to 3.7 million units by 2015. As the present-day transit area connecting Chinese harbours, factories and goods with ports and consumers all over Europe, the Middle East and North Africa, Greece is an important point along the Belt and Road. The "silk railway" along the so-called northern route from China to Europe (via Kazakhstan, Russia and Belarus) is another thread in the weave of the Belt and Road. The railway has been operating since June 2011, when the first freight train left Chinese Chongqing for Germany's Duisburg. It only took thirteen days to cross the distance. If we add all former Yugoslav countries, Romania, Hungary, Bulgaria, the Czech Republic, Slovakia, etc. and countries from other continents to the equation, we can see that the Belt and Road is simply a label for a megaproject of global proportions and significance. One of the prerequisites for the project is to build highquality infrastructure where it is lacking in a mutually beneficial way (the

Si Đinping, Zajedno preduzeti odgovornost vremena i unaprediti globalni razvoj, Almanah Instituta Konfucije XV-XVI, Filološki fakultet u Beogradu, 2017, pp.69-80. [The translation into English: Full Text: Xi Jinping's keynote speech at the World Economic Forum, The State Council Information Office (retrieved from http://www. china.org.cn/node_7247529/content_40569136.htm, accessed 8 December 2019).] 
famous win-win strategy). The idea is to form a network of connected "silk" routes for the flow of goods, ideas, people, cultural values, etc. Or, as the old Chinese proverb goes: Let the water flow if you want to breed fish.

The ancient Silk Road referred to the totality of human relations, to the meeting of civilization and the exchange of goods across the Eurasian space over the course of over two thousand years. It was an ancient transcontinental transportation and communication network, which was not developed during Han dynasty's China and the Roman Empire, as some are inclined to think, but had existed for thousands of years prior as a crossroads of various routes for the movement of people and goods. These routes, rather than one route, connected three continents: Asia, Europe and Africa. They crossed China, Afghanistan, India, Iran, Iraq, Syria, and Turkey, all the way to Rome. Ancient manuscripts reveal that people traded in jade, precious stones, gold, aromatic resin, aromatic milk, sesame seed, glass, fabric, silk, horses, bronze mirrors, wine, fruit, vegetables, paper, weapons, tea, hides, animals, people, etc. The goods were transported by mules, horses, yaks, camels, etc. But it was the exchange of ideas that spread along the route that was far more important for the meeting and understanding of civilizations. In this way, shamanism, Judaism, Buddhism, Manichaeism, Eastern Christianity, Islam, Western Christianity, Confucianism, etc. all mixed. Languages and alphabets, arts and literatures, religions and philosophies all became intertwined.

Now, what does the Belt and Road offer regarding the meeting of cultures of China and Serbia?

2.

As far as the meeting and cultural cooperation of China and Serbia through the Belt and Road are concerned, three events stand out. The first was the founding of the Confucius Institute in Belgrade at the Philological Faculty, University of Belgrade in 2006² the second was the 2014 international Belgrade Book Fair ${ }^{3}$, when China was the guest of honour; the third was the visit of Chinese President Xi Jinping to Serbia in $2016^{4}$.

Radosav Pušić (Ed.), Deset godina Instituta Konfucije u Beogradu, Filološki fakultet, 2016.

According to the majority of experts, China was the most successful guest of honour to date at the Belgrade Book Fair.

4 The significance of the visit, the agreements concluded during the visit, and the projects agreed upon by Serbia and China make this the most important visit of a Chinese president to Serbia in the history of the relations between the two countries. 


\section{THE CONFUCIOUS INSTITUTE IN BELGRADE}

The opening of the Confucius Institute in Belgrade (2006) launched a series of activities aimed at introducing various elements of Chinese culture and civilization into Serbia's cultural and social space. These included the celebration of Chinese holidays (the Spring Festival, Chinese New Year, the Mid-Autumn Festival), the National Day of the People's Republic of China (1 October), the Global Confucius Institute Day (23 September), etc. A plan was outlined for presenting various segments of Chinese culture, which included the Chinese Film Week, the Contemporary Chinese Photography Exhibition, the Chinese New Year Prints Exhibition, the Chinese Cuisine Course, Chinese Calligraphy and Painting Courses, the Chinese Paper-cut Exhibition, the Chinese Film and Documentary Festival, the Tai Chi Course, etc.

In 2012, a delegation from the Beijing Municipal Commission of Education visited Serbia. The delegation met with representatives of the Confucius Institute in Belgrade and made an arrangement for Chinese language learners from the Institute and secondary schools in Serbia to participate in the Beijing International Student Summer Camp, organized by Beijing's municipal government. Since then, our secondary school students have had great success in representing Serbia at this event.

Alongside exhibitions and celebrations, the Institute has also organized several series of lectures on Chinese religion, philosophy, art, literature, etc., held by prominent Serbian scholars. In order to promote interest in Chinese culture and language, the Confucius Institute and Serbia's Ministry of Education, Science and Technological Development conducted a teacher training seminar (Teacher Training Seminar for Local Chinese Language Teachers). In cooperation with the Embassy of the People's Republic of China, the Institute also held the Forum on Chinese Language Teaching for primary and secondary schools in Serbia, attended by one hundred school principals, staff members and Chinese language teachers from 47 primary and secondary Serbian schools. The forum saw open discussions on issues, current topics and difficulties in Chinese language teaching, as well as on the issue of promoting the interest of primary and secondary school students in Chinese culture and language.

The Confucius Institute in Belgrade also engages in scholarship and publishes research, monographs and books from various projects (the journal Almanah Instituta Konfucije u Beogradu ${ }^{5}$, a Chinese calligraphy

The first double issue of the journal Almanah Instituta Konfucije u Beogradu came out in 2009. 
textbook ${ }^{6}$, etc.). The Institute has also published the Curriculum for Chinese Language Teaching in Primary and Secondary Schools, Phonetic Rules for the Transcription of Chinese Syllables into Serbian, and several volumes on Chinese civilization. The Institute has implemented two projects: Linguistic and Cultural Comparison of Text Messages in Chinese, Serbian and English and Chinese Philosophy up to the Qin Dynasty.

The Institute has participated in several international events such as the international Archaeology Film Festival (organized by Serbia's National Museum and the relevant ministry), the international forum "Kontrapunkt" (organized by Serbia's Ministry of Culture), etc. Two international conferences were also held by the Institute: Modern China and Its Tradition (2008) and the Promotion of Chinese Language and Culture (2012). The opening speeches to these conferences were given by ministers from Serbia's relevant ministries and the Chinese ambassador. Through their research and participation, scholars from Serbia, China, Russia, the United States, Slovenia, Bulgaria and Switzerland all made a major contribution to the promotion of a wide variety of China-related topics.

The Institute has also participated in numerous art events. The visits of ensembles from the Northwest Normal University (2011) and the China University of Geosciences in Hubei (2014), organized by the Institute, have helped enhance the awareness of the great artistic ability of ensembles from China. If we also take into account the visits of Chinese artists organized by various government institutions in Serbia, the prominence of Chinese art can be said to have increased significantly over the last decade or so.

The National Museum of China from Beijing held the exhibition titled All Faces of Culture: the Painting and Life of Scholars in Ancient China (November 2018 - February 2019), comparable in importance and scope to the exhibition Royal Bronze: the Treasures of Chinese Xia, Shang and Zhou Dynasties, dedicated to the era of the oldest Chinese dynasties Xia, Shang and Zhou (59 exhibits: pots, musical instruments, agricultural tools, weapons, coins, mirrors, horse tack and carriages), which was held at the Museum of Yugoslav History in 2006.

The Confucius Institute in Belgrade worked with the steel manufacturer Železara Smederevo and provided both Chinese language courses for its Serbian employees and courses on Serbian culture and language for its Chinese engineers and workers (two cycles of classes for Hestil employees in 2017), which undoubtedly helped the company's employees to become better adapted culturally and overcome intercultural differences.

Li Đunming, Jen Čenćingova kaligrafska tehnika standardnog pisma (stilaKai) iz dinastije Tang, Filološki fakultet, 2010. 


\section{2014 BELGRADE BOOK FAIR AND THE 2016 VISIT OF CHINESE PRESIDENT XI JINPING}

China was the guest of honour at the 2014 Belgrade Book Fair. The delegation of Chinese writers consisted of the most illustrious figures from China's literary world such as Liu Zhenyun (who opened the Fair), A Lai, Zhang Yueran, Yu Hua, Mai Jia, etc. The central area of the Chinese pavilion featured books describing "the Chinese dream and the Chinese path". Interestingly, the slogan chosen by the Chinese guests was "Books Cultivate Friendships, Cooperation Builds the Future". The Chinese stand at the Fair had a small tea room, where the visitors could enjoy a tea ceremony. The Confucius Institute in Belgrade put together a Hanban stand at the Fair, as well as a series of events such as a public Chinese language lesson and the presentation and promotion of Chinese books. The presentations and discussions - "Chinese Literature and Chinese Society", "China: Children's Books and Books for Young Adults", "Translated Works from Chinese Literature", "Chinese Literature Today: the Traditional and the Contemporary", and "Chinese Poetry Today" - were moderated by the director of the Confucius Institute in Belgrade. The exceptional atmosphere created by Chinese publishers at the Fair and elaborate and exhaustive presentations on Chinese writers, Chinese literature and contemporary China undoubtedly increased the interest for these aspects of Chinese culture in Serbia. During the book fair, China set up 89 different events, one forum, five discussions, 56 meetings between publishers and 27 meetings between writers. The publication of a large number of books, successfully, meticulously and skilfully translated from Chinese, introduced Serbia to the rich tapestry of Chinese literature for the first time. The book fair also included the Serbia-China literary forum "The Development of Publishing and Cultural Cooperation between China and Serbia". Asked to comment on China as the guest of honour at the book fair and forum, Senior Adviser at the Department for International Relations of the Ministry of Culture and Information Mladen Vesković called the Chinese visit a first-rate cultural event, pointing out that: "This is an exceptional opportunity for Serbian and Chinese publishers, graphic designers, digital artists, distributers and representatives of the printing industry to come together and consider all possible forms of business cooperation as well as joint ventures in other countries." 7

Mladen Vesković, Veze Srbija - Kina, Almanah Instituta Konfucije XI-XII, Filološki fakultet u Beogradu, 2015, pp. 137-140 
Chinese President Xi Jinping came to Serbia for a three-day visit between June 17 and June 19 2016. This was the first visit of a Chinese president in 32 years. Chinese President Xi Jinping and Serbian President Tomislav Nikolić laid the foundation for the Chinese Cultural Centre at the location of the Chinese embassy destroyed during NATO's aggression against Serbia. At the event, they also unveiled a monument to Chinese philosopher Confucius. Economic matters that took place during the visit included an agreement to build a motorway between Surčin and Obrenovac and the takeover of the steel manufacturer Železara Smederevo by Chinese Hestil.

The visit of Chinese President Xi Jinping to Serbia was an event with the potential to change not only the relations between the two countries but also the cultural policies relating to those relations. In cooperation with the Embassy of the People's Republic of China in Serbia and the Office of the President of the Republic of Serbia, the Confucius Institute in Belgrade, or rather some of its students, gave a performance during the celebratory dinner. The prominence of the Confucius Institute in Belgrade during the visit of the Chinese president was not only a sign of recognition of its work but also an opportunity to demonstrate at the highest official level the cultural cooperation between the two countries and peoples in practice.

The founding of the second Serbian cultural centre in the world, which was opened in Beijing, China by Serbia's Minister of Culture Vladan Vukosavljević and China's Minister of Culture and Tourism Luo Shugang, serves to complete the picture of the cultural ties between the two countries in the past twenty years or so. The cultural centre was named "Ivo Andrić" after our Nobel Prize Winner. On this occasion, the Serbian Minister of Culture said:

I believe and hope that the Ivo Andrić Cultural Centre will be a home not just to Serbian culture but a true home to the friendship between the Serbian people and the Chinese people. Bridges that abolish obstacles between people and nations are the central symbol in the works of Ivo Andrić, whose novel The Bridge on the Drina was translated into Chinese a long time ago. May the institution that we are opening tonight be a sturdy and lasting bridge between our friendly nations. ${ }^{8}$

There are more than three million inhabitants living in the economic belt along the Silk Road, with large markets and enormous potential. The diversity of their historical and cultural heritage not only obligates but also necessitates cultural cooperation and exchange.

Report from the opening of Serbia's cultural centre in Beijing, published in Politika. http://www.politika.rs/sr/clanak/416882/Otvoren-Kulturni-centar-Srbije-u-Pekingu 
Everything man does is reflected in natural and cosmic realms. Cultural cooperation, which is perhaps the best and most pervasive element of interpersonal and international relations, has a mission. Two words are closely connected to it - 'dream' and 'road'.

Translated by Jelena Bošnjak

\section{REFERENCES}

1. F. Bergsten, Č. Frimen, N. Lardi, D. Mičel, Uspon Kine, Službeni glasnik, Beograd, 2011.

2. Martin Jacques, When China Rules the World, Penguin Books, England, 2012.

3. Almanah Instituta Konfucije XI XII, Filološki fakultet u Beogradu, 2015.

4. Almanah Instituta Konfucije XV XVI, Filološki fakultet u Beogradu, 2017.

5. Piter Frankopan, Putevi svile, Laguna, Beograd, 2018.

6. Piter Frankopan, Novi putevi svile, Laguna, Beograd, 2018.

7. Džou Tijenjung, Kineski san i kineski put, Čigoja, Beograd, 2019. 